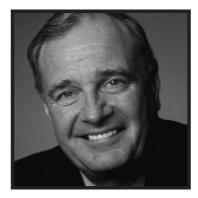

\title{
A Passionate Plea: Equal Educational Opportunities for All Canadians
}

\author{
The Right Honourable Paul Martin
}

\section{ABSTRACT}

Former Prime Minister Paul Martin discusses the importance of providing equal educational opportunities to all Canadians, particularly to our First Nations, Métis and Inuit people. He describes the propelling force behind the Kelowna Accord, which made history by bringing together Federal, Provincial, Territorial and Aboriginal peoples leaders to resolve critical problems related to education, among other things. Mr. Martin's interest in Aboriginal education has led him to participate in four important initiatives that focus on improving K-12 education in Aboriginal communities: a Promising Practices Web site for teachers, a Mentorship Program for high school students, a Model School Program aimed at primary schools, and a Business Education Program focused on preventing dropout. He describes these programs, and the results they are achieving. Finally, Mr. Martin offers words of advice for parents, youths and governments for the future of education in Canada.

Mr. Martin, what educational experiences, informal or formal, do you believe contributed to your success as a politician and an entrepreneur?

(Editor's Note: Any reprints, video or other linked to this article should be verified with the Office of the Right Honourable Paul Martin at http://www.paulmartin.ca/en/contact)

ell, there is no doubt that having good primary, secondary and, obviously, university education is very important if, in fact, there are a number of avenues which you want to follow that might well otherwise be 
foreclosed. And I was very lucky in that way. As well, informal education is important, as are the examples that people set. I would say probably my father had the greatest influence upon my life. He came from a very poor family, and was the first person in his family to go to university. He understood the role of government in helping those who were not born to wealth essentially to have the opportunity to take advantage of everything that is out there.

Other people, like Maurice Strong, who was one of Canada's first great environmentalists, influenced me heavily in terms of the Third World and the environment. Then, of course, there were my experiences working up north. I worked north of 60 a number of summers to put myself through school. And it was there, really, that I came to really know young people my own age who were either First Nations, Inuit or Métis and I saw how different and how valuable their life experiences were. Unfortunately, in our system they just were not able to take advantage of what Canada has to offer.

So I think it is a combination of all these things. There is no doubt that a university that teaches you what life is about in terms of the great studies that have been achieved is very important. But also, to then be able to take that and be able to see it in the eyes of people who are living different kinds of lives is also extremely valuable.

Can you describe some memorable experiences you had as a student at any level of education, and why these stand out in particular?

Oh, any one of a number. I will tell you perhaps of the one set of lectures that will always stay with me (this is at the University of Toronto and my minor was in history)...I walked into the auditorium where this particular course was being taught and there must have been a thousand people in it. And this was usually a small class. I thought, I have walked into the wrong room. I couldn't understand it. And they said, No, no, no. This is a series of special lectures that is given every year by one of the professors. The first lecture was on the Reformation. It was how, in fact, those who had protested (meaning Protestants) had basically brought about the Reformation. I am a Catholic. And at the end of that lecture Catholics would leave saying, Oh my heavens, what was that all about? 
The second lecture was on the Counter-Reformation. And when the Protestant students came out of the room, they'd ask themselves the same question. Both sides of the divide then understood just how intense the Reformation and Counter-Reformation were. And then the third lecture was when everything was reconciled. And I must say that if I were to pick one series of lectures, it was certainly that.

One of your major accomplishments as the $21^{\text {st }}$ Prime Minister of Canada was the signing of the Kelowna Accord in 2005. Can you talk about the efforts that went into this agreement, what has been accomplished as a result, and what you envision for the future?

Well, essentially, the world's treatment of its indigenous peoples has been simply unacceptable. The damage that we have done to so many people is virtually unspeakable. This is true in Australia, it is true in Africa, in South America, and it is certainly true in the United States and in Canada.

Essentially, what we did when the settlers first arrived was to say to the First Nations, the Métis and the Inuit, that everything that we believe is good and everything that you believe is bad. We were the dominant economic force and as such we burdened them for 300 years with that mantra. And yet, despite all of that, their desire to hold on to their traditions, their identity, is there. This is a wonderful thing that speaks so highly of Canada's Aboriginal peoples. But the fact is that the entire system was built against them-housing, water, the residential school issue where we turned education into a way to assimilate them and destroy their traditions - all of this is part of our history and, in fact, it is very much a part of our contemporary reality. The last residential school did not close until the early 1990s, as an example.

Thus one example of the purpose of the Kelowna Accord was in education. It was to recognize that governments have been under-funding primary and secondary school education on reserve compared to what the provinces do off reserve. As well, we under-fund welfare, we under-fund hospital care and healthcare; the housing conditions, the potable water conditions ... all of this is just an absolute national disgrace.

So, what the Kelowna Accord said was, we are going to right this. History is going to change, and it is going to change now in terms of these areas which are such 
fundamental parts of Canadian life. In the past what the Canadian government had done was to simply say, there is a problem, here is a solution-and ignore the Aboriginal leadership. We said we are not going to do that. What we are going to do is work in partnership. During the 15 months before we met in Kelowna, we sat down with First Nations, the Métis and Inuit leadership in this country, and we said, how do we deal with these issues? What do you think?

And every bit as important, because the provinces deliver healthcare and education, we said we want the provinces and the territories at the table. That is the first time in the history of Canada that provincial, territorial and Aboriginal leadership and the federal government were at the same table.

In 15 months we worked out a plan among all of us as to how we were going to deal with these issues and how they should be funded. And then we met in Kelowna-Canadian Prime Minister, pertinent ministers of the Federal Cabinet, all the provincial premiers, the Territorial leaders and the Aboriginal leadership-and we came to an Accord, televised in front of 33 million Canadians, in which we said the history of this country is going to change in terms of the essential elements that give a person a chance to succeed in the 21 st century. And that is the Kelowna Accord.

Another important initiative into which you have put energy and resources is the Martin Aboriginal Education Initiative. Can you talk about the impetus for this initiative, what has been accomplished so far, and what lies ahead in the future?

Well, the reason for doing this is that, as I mentioned earlier, I had worked up north with the Aboriginal communities and I have a lot of friends there and I understood what they had gone through in their lives. They were not given the same opportunities as the rest of us. Fundamentally, it comes down to education available to other Canadians.

Forty-four per cent of all Aboriginal students in the provincial school system do not graduate; 60 per cent of all First Nations on reserve do not graduate. And the difference between having a high school education and not having a high school education in terms of quality of life, the opportunity for a good job-and, obviously, the opportunity to go to university-is overwhelming. 
There are reasons for this. The fact is that on reserve, for instance, the schools are isolated. There is no such thing as a school network. Furthermore, the federal government does not deliver elementary and secondary school education as do the provinces, therefore it does not have the requisite background or skills. Many Band Councils do not have the kind of skills that they should have. You have to remember that up until 1953 if you were a Status Indian you were not allowed to go to university. So we decided that we would focus (this is when I stepped down from government) on education.

But Canada's universities are doing a tremendous job.I mean, they are playing catch-up, but I have to say that over the last 10 to 15 years what our universities have done in terms of Aboriginal education has been awe inspiring. The same is not true at the primary and secondary school level. So we decided to focus on that.

We have four programs. One of them is what we call the Promising Practices Web site, which is simply taking all the best ideas, $\mathrm{K}-12$, and putting them on a Web site, because $\mathrm{K}-12$ is a problem not just for Aboriginals. It is a problem in Canada, it is in the United States, the United Kingdom, right throughout the AngloSaxon world. Fortunately there are all kinds of good ideas, initiatives that are taking place to deal with these issues or problems. However, they never translate over to Aboriginal education. So we decided to put up the Promising Practices Web site and make them available to all the Aboriginal educators in the country.

Our second program is a Mentorship Program. I was trained as a lawyer, and yet before I went into politics I ran a shipping company. Well, people said, how could you ever know how to run a shipping company? Well, the answer is simple: somebody taught me. I was mentored. And so, we met with the Association of Chartered Accountants and they have agreed to be mentors. They said, we have offices throughout the country. If you will start to offer students to us who might drop out but have an eye for detail, an eye for math, we will start to mentor them and give them internships in high school. Maybe that will keep them in high school and they will want to go to university, and maybe some of them will become chartered accountants. Well, that's the second program.

The third initiative, which we just started in two elementary schools on a reserve in Southwest Ontario, is our Model School Program. There are good primary schools on reserve; but there are also an awful lot that are not really up to snuff. The province of Ontario has a tremendous program, an At-risk Grade School Program. [The challenge is]:"How [to] take a grade school which is not functioning very well 
and give it the skills to be able to teach literacy and mathematics [just like] the best grade schools in North America." So, we have taken that program, we hired the lead teachers, and we are going to do a pilot in these two primary schools with the full support of the principals and the Band Councils. Hopefully it's going to work, and what they will be able to do is meet all of the provincial tests. They will then become model grade schools, and then we will extend that program throughout the rest of the country. But we really hope that at that point governments will start to pick it up.

The last program I would mention was in fact our first. It is based on the insight that students who are dropping out of school will stay in school if they can see that they will be taught something concrete, fundamentally something that may well give them a better life later on. A teacher, some 30 years ago in the inner city of New York, discovered that if you teach potential dropouts business they will stay in school. This program is now in 14 countries-the United Kingdom, in Ireland, in Israel, in Belgium, and 30 U.S. States. We took the program and married it with the Ontario curriculum and introduced it as a pilot project on a reserve school in Thunder Bay, a reserve school that is dealing with kids who come from fly-in communities down the coast of Hudson Bay and James Bay, and the program is working tremendously well.

As a result of that, I called the Premiers of the four western provinces and the Premier of New Brunswick and I said, send your education people to take a look at this. And they did. We now have a school in British Columbia, we have a school in Alberta, a school in Saskatchewan, a school in Manitoba and we're opening next year in New Brunswick. Our intention is, essentially, once we get enough of these schools across the country, then we want to start to expand them within the individual provinces because in terms of keeping kids in school, they are really working quite well. We also open next year in Laurentian University.

In educational initiatives, student voices are most often left out of the equation. This has not been so in the MAEI Initiative. Can you tell us some stories of these mentees?

One of the interesting issues is Aboriginal leaders tell you how important it is to know one's identity. In other words, if you do not have an understanding of who you are, then you are not going to be open to continuing education. I wondered about this at first. So one of the things that I have done, when I go to meet the 
students (and I do this a lot) I ask them, how important is it for you to know who you are and what you are about? Students never cease telling me about their background and why it is important for them to be able to stand tall as Cree, or a Chippewa or a Mohawk and what it means to them.

But what is most interesting is that the more education a young person has the more that identity is important to them.

In our business program, the students basically develop businesses. Aboriginal students have incredible artistic talent. They are great painters. I do not mean just great painters as students; there is a huge talent out there and the same thing with music.

I'll never forget the first time we visited Thunder Bay and all of these students had their programs and their various businesses. A number of them were related to music. One of them had a program where it was sort of a Karaoke-type thing, which you would take around with you and you would come out and play a guitar and the guitar would actually play. So I tried it. Then they showed me what I looked like on the screen. And I have to say it took me about six months before I could go back to the school, because I have to say that they have to still be telling the story about how clumsy and how I must have anvils for hands. And they had a great deal of fun out of that.

One of the student's businesses was designing comic books. He showed me his first book. It really is one that I think at some point should win a prize. It was about his best friend who had committed suicide. It was to be distributed to other young students so that they would understand just what a terrible thing suicide is. It was impossible for me to read it without crying.

We really are breaking new ground here. Teachers are tremendously dedicated to the work, but unless you go to the students and say to them, look, is this working for you? And if it's not working for you, what would make it work for you? well you will never succeed. I found that the students had huge talent. What we find often times is that we'll go with the first class at the very beginning. I'll go around and some of them are so shy they're barely able to tell you their names. Six months later they're standing up in front of 200 or 300 people and they're describing their business. Where does that self-confidence come from? I think it is because they're young. It is easier for them to develop that self-confidence if somebody is supporting them. I'll give you another example. At the beginning we had competitions. There would 
be 20 kids who would put their business programs up front and then we would bring in a jury who would pick first, second or third.

And when we had done that the first time, I said, You know, I don't think this is a good idea. I don't think having these kids test their ideas against each other makes a lot of sense.

And so I said to the teachers and to the school, I think we should just let them make their presentations. Then the teachers went to the kids and told them this. The kids said, no, no; we want to have that contest. They said, you misread us, we want to stand the test. This is what it is all about. They actually understood the program better than I did.

In an ideal world, what would you envision for the future of Canada's educational system, and what major challenges must be faced?

Well, I'm not an educator. I spent a lot of time in school, but I was always on the other side of the desk. But I think I do have a bit of an understanding of Aboriginal education. I think first of all, proper funding. Let me give you an example in the province of Ontario (but it is the same way across the country). In the province of Ontario the federal government gives $\$ 12,000$ per capita per student to the province to educate an Aboriginal who lives on reserve who is going to go to an offreserve high school. But for an on-reserve high school, they give the Band $\$ 6,000-$ 50 per cent of the cost. Look, if I am spending $\$ 12,000$ on your education, and $\$ 6,000$ on somebody else's, well there is no doubt that there is going to be a difference in the quality of that education.

Second: we have to understand that there are a lot of damaged young people out there either as a consequence of their parents going to a residential school, or their grandparents, or as a result of things like fetal alcoholic syndrome and there has to be greater funding for kids with disabilities or special needs.

Third: we have to understand how important identity is, and how important an understanding of others' tradition. For instance, Foreign Service officers whose children are going to the French School, or the American School in foreign postings will come back and they will talk about the cultural difference prevalent. They will say that "it is taking my child a while to understand it." Or, if they have gone 
to the American School or the French School for all of their lives and all of a sudden they come back to Canada and they have to make an adjustment ... well, just think what it is like if you are a young boy or girl living in an isolated community of 300 people on the shores of Hudson Bay, and then all of a sudden at the age of 14 you are sent to a reserve school in Thunder Bay and you live in a boarding house. Just think about the cultural shock that represents. Or, if your family has moved from northern Saskatchewan to Regina or Saskatoon, and all of a sudden you are living in a community, and there are problems at home ... and just think of what those young people are going through. Our education system is simply not up to dealing with that, and it has to be.

Aboriginal Canadians are the youngest and fastest growing segment of our population. It is immoral not to treat those young people the same way as you would treat anybody else and to recognize their differences. But it is economically dumb as well.

We are 33 million people. We are competing with countries with massive populations and we cannot afford to waste a single talent.

As a parent, grandparent, politician, business person, philosophy minor, historian, lawyer and a citizen, what advice can you offer young students, their parents and teachers?

Well, as far as the parents are concerned, I think that they should sign a contract with your children that you're going to make them go to school and that you're going to make them do their homework and that you're going to make them understand what it is they have to do.

I've got to tell you that I am certainly impressed with the teachers involved in aboriginal education I have met-the grade schools teachers, the primary school teachers, the high school teachers, and obviously the university professors.

They are really, truly dedicated people. I think they need a lot more support in some areas. It is impossible not to see when you realize what a contribution they are making, that they should not be given far greater recognition. 
As far as the students are concerned, I think that for the problems that inevitably occur in the teen years that they occur in everybody's teen years; not just in the early years of Aboriginal students. I believe that you've got to give them a sense of what the outside world is all about so they know what it is that they are going into. You've got to give them a sense of confidence. 


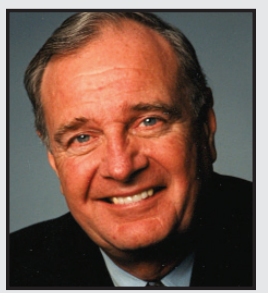

The Right Honourable Paul Martin was the twentyfirst Prime Minister of Canada from 2003 to 2006 and its Minister of Finance from 1993 to 2002 and the Member of Parliament for LaSalle-Émard in Montreal, Quebec from 1988 to 2008 .

In November 2005, under Mr. Martin's leadership, the Canadian Government reached a historic consensus with Canada's provinces, territories, First Nations, Métis and Inuit leaders that would eliminate the gaps between Aboriginal and non-Aboriginal Canadians in the areas of health, education, housing and economic opportunity. This agreement became known as the Kelowna Accord.

Domestically, he is leading two new initiatives. The Martin Aboriginal Education Initiative which aims at reducing the Aboriginal youth dropout rate and at increasing the number of Aboriginal students attending post-secondary institutions. He also founded, along with his son David, the Capital for Aboriginal Prosperity and Entrepreneurship Fund, whose investments seek to further a culture of economic independence, ownership and entrepreneurship amongst both on and off reserve Aboriginal peoples, through the creation and growth of successful businesses.

Mr. Martin studied philosophy and history at St. Michael's College at the University of Toronto before obtaining his LL.B. from the Faculty of Law at the University of Toronto. He was called to the Ontario Bar in 1966.

LINK TO:

www.maei-ieam.ca 